extrapolate linearly from the concept of replacing a defective allele by a functional one to the notion of superlatively functional or desirable varieties of gene. We can imagine the usefulness of inserting a gene into a haemophiliac, to produce adequate levels of factor VIII in serum. What would a better factor VIII gene do? Produce ten times as much? - and if so, would this be a good thing? Genes with effects on anatomy, behaviour or intelligence contribute to phenotypic effects in the context of interactions, at biochemical, cellular and tissue levels, with other genes in the individual and with the environment. An allele which confers advantage in one genetic and environmental context can make a neutral or negative contribution in others. For a range of reasons, most genes would require to be inserted in the egg. The necessity would then be to identify and obtain the appropriate gene, to identify the genotype of the egg, to insert the gene correctly, and to reimplant the egg, and it will be necessary to have total success at all stages of the manipulations. This is not merely a question of technique chemical reactions and cell interactions are stochastic processes: randomness and error are inbuilt, and cannot be eliminated. We have not yet domesticated Maxwell's demon. How would Dr Glover advise on the disposal of failed experiments? No, don't hope to buy a gene off the shelf to produce a super-person. Far better concentrate on making conditons possible for an enriched environment - we already know that this can produce remarkable results.

We must also consider resource allocation. We already have the means of identifying well over 200 genetically disadvantageous conditions in the fetus. Identification followed by termination has significantly reduced the numbers of individuals suffering from, for example, Tay-Sachs disease, or thalassaemia. The availability of skilled practitioners and or resources for this technique is nowhere near commensurate with need - yet it is far less demanding in all respects and has fewer chances of accumulating errors than would genetic salvaging or improvement of each suboptimal fetus. It is also more appropriate to the problems of our overcrowded planet. Genetic engineering is more likely to be useful for the production of specific gene products, or for certain conditions which might be managed by, for example, modified bone-marrow cells, or for animals or plants which may then be propagated indefinitely afterwards under controlled conditions. It is worth remembering, however, that there will be chemical and physiological limits to the milk yield of a cow, or the numbers of ears of corn on a maize plant.

Dr Glover's concern with possible future methods of modifying personality or behaviour will surely strike a chord with all his readers - yet personality and behaviour are already powerfully affected by such factors as the exercise of power, or by being victim and powerless, by deprivation, by the formation of mobs, by expected social roles, by rigid upbringing, and by skilled manipulation of public and private opinion and responses. We know through Amnesty reports of procedures developed and used in many countries to damage the character and spirit and to modify behaviour. Recently there have been first-hand reports from Vietnam veterans who were trained for 'special missions' in the so-called 'Boot camps' in the USA by horrific techniques of personality alteration so that they became murderous automata and are now unable to live as social beings, but remain isolated in the American wilderness.

Changes for the better in the future are more likely to be brought about by focusing on social structures, economics, education, and indeed, the whole of the human ecology. The horrors of the future are more likely to be averted by attention to the politics of the present, than by raising the eyes above the problems of today and gazing instead into the infinite void.

RUTH CLAYTON Reader, Department of Genetics, Edinburgh University, West Mains Road, Edinburgh 9

\section{Artificial Reproduction: a Social Investigation}

\section{R Snowden, G D Mitchell and E M Snowden, 155 pages, London, £9.95, George Allen and Unwin, 1983.}

The authors here record the results of their joint research project which, they say, has 'concentrated on the most common form of artificial reproduction, namely, artificial insemination by donor semen (AID)'.
But, they add, 'our interests have also extended to the social issues surrounding other forms of artificial reproduction'. They begin by describing the different ways of achieving procreation without engaging in sexual intercourse, and go on to propose a whole range of new technical terms for describing the agents and techniques involved. For example, they suggest 'genetic mother' for the woman who provides and matures the ovum, 'carrying mother' for the woman who brings the child to birth, and 'nurturing mother' for the woman who takes care of the child once it is born. They also recommend that the phrase 'in vitro fertilisation' be scrapped in favour of 'external human fertilisation'; but while their case for this substitution (p 29) is plausible, the former phrase is so widespread now that I suspect the authors are championing a lost cause here.

Chapter Three, on The Family, is important and valuable. The authors argue that 'we have two essential ingredients when describing family life: first, an exclusive sexual relationship, and secondly the birth, nurturance and upbringing of children. Family and marriage are thus concerned primarily with issues surrounding reproduction' (p 44). They regard these two characteristics as so essential to marriage, and marriage itself as so indispensable to the good of society, that they recommend that artificial reproduction, in whatever form, should take place only when the couple nurturing the child are married (p 169).

In Part II of the book the authors describe their research project, which involved studying the experiences of 899 couples who underwent AID treatment between 1940 and 1980, and interviewing 66 couples who are the parents of one or more AID children. How have people coped with infertility? Why is male infertility popularly invested with much more of a stigma than is female infertility? Do couples with AID children try to keep those children's origins from them as well as from close relations and friends? Should they do so, or is such secrecy itself a cause of anxiety which should be removed? The authors explore all these questions and many more, arguing that openness towards AID children and towards close relations and friends is the policy which produces the best results in terms of the peace of mind and freedom from stress of both parents and children.

The final two chapters, Artificial Reproduction and Society, and 
Conclusions and Recommendations, are particularly interesting in view of the controversies aroused by the Warnock Report. Many of the recommendations contained here are similar to Warnock's (for example, concerning the legitimacy of AID children, the need for a licensing authority to supervise the work of AID and IVF centres, etc), but others are at odds with the corresponding Warnock recommendations. In general, the authors place higher value on the family as an institution than did the Warnock Committee and display a much livelier awareness of the possible social dangers of the new techniques.

One weakness of the book is that since its authors are approaching these topics from the standpoint of social scientists, their recommendations for legislative action - which surely must be based on properly ethical considerations, not merely sociological ones - seem devoid of any satisfactory rational support. For example, they concede that experimentation on human embryos is an objectionable practice, since 'the material acting as the subject of the experimentation is a human being at the beginning of its individual development' ( $p$ 178); but the practical recommendation which they make concerning this practice is disappointingly feeble:

'The value placed upon human life is so great that experimentation upon human embryos should only be undertaken if it can be shown to be in the public interest.' (p 179.)

But if the embryo is really a human being then surely experimentation upon it is morally wrong regardless of whether it is in the public interest or not? Here, I suspect, the authors' concentration on sociological issues leads them to overlook the crucial moral issues at stake and unthinkingly to adopt a fashionable but extremely dubious consequentialism on this and some other important issues. But as a social investigation this book is very worthwhile and deserves to be widely read. It is also refreshingly free from the pretentious jargon which sometimes disfigures studies of this sort.

F J FITZPATRICK Education and Research Officer, The Linacre Centre for the Study of the Ethics of Health Care, London

\section{Ethics and the Limits of Philosophy}

Bernard Williams, 230 pages, London, $£ 10.95$, Fontana and William Collins, 1985.

Moral philosophy can be relevant to a medical readership although it does not deal specifically with the problems encountered in medicine and nursing. This is because moral philosophers can offer discussions of concepts such as harm, consent, quality of life, paternalism and many others which encapsulate the moral problems of medical and nursing practice. But there are also treatises on moral philosophy which, while doubtless admired by professional philosophers, seem to the layman to be remote from the moral problems of ordinary life and professional practice. This book is in the latter category rather than the former. It is simply not true to say, as the cover does say, that it does not demand a philosophical training to follow'. The difficulty is not that technical words are used but rather that the argument proceeds at a high level of abstraction from real-life moral problems. It offers a theory about other theories.

The theory it offers has two main strands in it. The first is that the Socratic question, 'How should one live?' is an ethical question as distinct from merely a moral one, and that we would all do better to concentrate on the 'ethical' and drop the 'moral'. The trouble with the working out of this theme however is that the sphere of the ethical is left vague, and morality with its obligations, which we would be better without (p 174), is liable to reappear disguised as the ethical with its 'shoulds'. The second strand is that 'The resources of most modern moral philosophy are not well adjusted to the modern world' (p 197). The case for this is not really made out, and readers of this journal will appreciate that within its pages at least there is some moral philosophy which does sometimes succeed in adjusting to the moral problems of the modern world. Nevertheless, there are many excellent discussions in the book of such matters as objectivity and relativism (chapters 8 and 9). The general conclusions are negative, although sometimes this stems from a humility about what can be achieved by moral philosophy, and an admiration for what has been achieved by science. But the pessimism about the relevance of moral philosophy to the modern world was more apt in the period 1950-70. Nowadays many philosophers have tried to apply theif analytical skills to problems in medicine, politics, the environment an so on. Indeed, Williams himself was entirely appropriate as the Chairman of the Government Committee on Obscenity and Film Censorship, and of course Mary Warnock chaired another famous committee. Both of these were attempts to adjust moral philosophy to the modern world. No doubt there is still room for improvement in moral philosophy, but the improvement does not require a distinction between the ethical and the moral or another conception of rationality, but rather some homework on what scientists, doctors, economists etc actually say.

R S DOWNIE Professor of Moral Philosophy, Glasgow University

\section{Cecily Pembroke \\ Would the person who sent us a case study about Cecily Pembroke please write to the Editor. It arrived without any covering letter and our detective work is not up to the task of tracing its author(s).}

Editor 